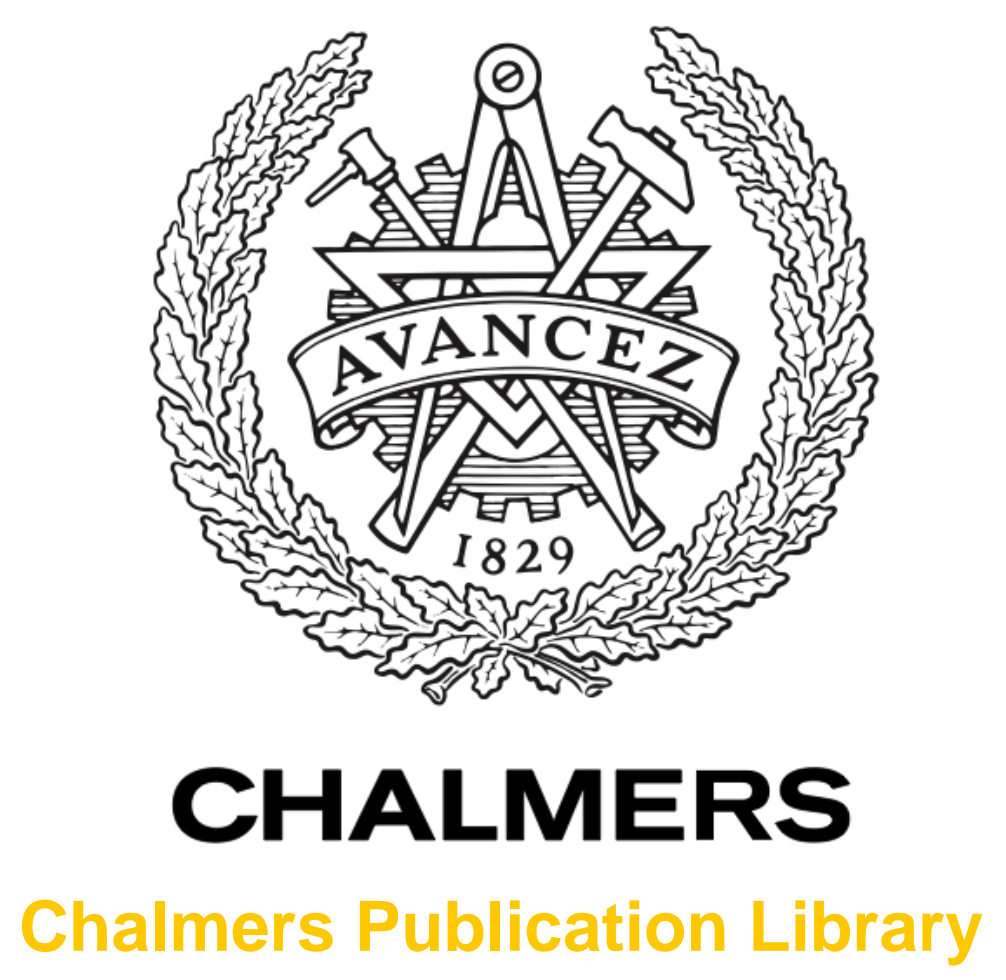

\title{
Exergy-based comparison of indirect and direct biomass gasification technologies within the framework of bio-SNG production
}

This document has been downloaded from Chalmers Publication Library (CPL). It is the author's version of a work that was accepted for publication in:

Biomass Conversion and Biorefinery (ISSN: 2190-6815)

Citation for the published paper:

Heyne, S. ; Thunman, H. ; Harvey, S. (2013) "Exergy-based comparison of indirect and direct biomass gasification technologies within the framework of bio-SNG production".

Biomass Conversion and Biorefinery

http://dx.doi.org/10.1007/s13399-013-0079-1

Downloaded from: http://publications.lib.chalmers.se/publication/178512

Notice: Changes introduced as a result of publishing processes such as copy-editing and formatting may not be reflected in this document. For a definitive version of this work, please refer to the published source. Please note that access to the published version might require a subscription. 
The final publication is available at http://link.springer.com/article/10.1007/s13399-013-0079-1. Published in Biomass Conversion and Biorefinery 2013, DOI: 10.1007/s13399-013-0079-1

Stefan Heyne ${ }^{1}$, Henrik Thunman ${ }^{2}$, Simon Harvey ${ }^{1}$

\title{
Exergy-based comparison of indirect and direct biomass gasification technologies within the framework of Bio-SNG production
}

\author{
${ }^{1}$ Division of Heat and Power Technology, Department of Energy and Environment, Chalmers University of \\ Technology, Göteborg, Sweden \\ ${ }^{2}$ Division of Energy Technology, Department of Energy and Environment, Chalmers University of Technology, \\ Göteborg, Sweden
}

\begin{abstract}
Atmospheric indirect steam-blown and pressurised direct oxygen-blown gasification are the two major technologies discussed for large-scale production of synthetic natural gas from biomass (Bio-SNG) by thermochemical conversion. Published system studies of Bio-SNG production concepts draw different conclusions about which gasification technology performs best. In this paper, an exergy-based comparison of the two gasification technologies is performed using a simplified gasification reactor model. This approach aims at comparing the two technologies on a common basis without possible bias due to model regression on specific reactor data. The system boundaries include the gasification and gas cleaning step to generate a product gas ready for subsequent synthesis. The major parameter investigated is the delivery pressure of the product gas. Other model parameters include the air-to-fuel ratio for gasification as well as the $\mathrm{H}_{2} / \mathrm{CO}$ ratio in the product gas. In order to illustrate the thermodynamic limits and sources of efficiency loss, an ideal modelling approach is contrasted with a model accounting for losses in e.g. the heat recovery and compression operations. The resulting cold gas efficiencies of the processes are in the range of $0.66-0.84$ on a lower heating value basis. Exergy efficiencies for the ideal systems are from 0.79 to 0.84 and in the range of 0.7 to 0.79 for the systems including losses. Pressurised direct gasification benefits from higher delivery pressure of the finished gas product and results in the highest exergy efficiency values. Regarding Bio-SNG synthesis however, a higher energetic and exergetic penalty for $\mathrm{CO}_{2}$ removal results in direct gasification exergy efficiency values that are below values for indirect gasification. No significant difference in performance between the technologies can be observed based on the model results, but a challenge identified for process design is efficient heat recovery and cogeneration of electricity for both technologies. Furthermore, direct gasification performance is penalized by incomplete carbon conversion in contrast to performance of indirect gasification concepts.
\end{abstract}

Keywords: biomass gasification, fluidised bed gasification, exergy analysis, Bio-SNG, biofuels 


\section{Background:}

The production of synthetic natural gas from biomass (Bio-SNG) via thermal gasification is a process for second generation biofuel production that is close to commercialisation, with several industrial scale projects ongoing [1-3]. For the major conversion step from solid to gaseous state - the thermal gasification process - two technology options are available: indirect or allothermal gasification with steam as gasification agent and direct or autothermal gasification with a mixture of oxygen and steam. Two large industrial Bio-SNG projects currently conducted in Sweden are planning to implement different gasification technologies, with the GoBiGas project using indirect gasification [1] and the Bio2G project applying direct gasification [2]. The GoBiGas project is currently constructing its phase 1 plant producing $20 \mathrm{MW}_{\mathrm{SNG}}$ that is scheduled to be in operation by November 2013. Based on the experience from phase 1 it is planned to build a second plant resulting in a total capacity of $100 \mathrm{MW}_{\mathrm{SNG}}$. The Bio2G project aims at $200 \mathrm{MW}_{\mathrm{SNG}}$ production based on direct gasification but this project is currently put on hold due to uncertain economic conditions [4]. Hamelinck and Faaij [5] state that for a number of biomass-based fuel production routes, systems based on pressurised gasification have higher energy conversion efficiencies than atmospheric gasifier-based systems.

In system studies of SNG production from biomass no clear consensus has emerged about which gasification technology leads to higher efficiency. A modelling-based comparison of entrained flow, indirect, and direct $\mathrm{O}_{2}$ blown gasification technology [6] states that indirect gasification has a cold gas biomass to SNG efficiency of 67\% (LHV-basis) compared to direct gasification (58\%, LHV-basis), accounting for the net process electricity balance. Gassner and Maréchal $[7,8]$ use a multi-objective optimisation approach for systematically synthesizing Bio-SNG process schemes including heat recovery systems for power generation, optimizing them for thermodynamic and economic performance. They conclude that pressurised $\mathrm{O}_{2}$-blown gasification outperforms indirect gasification both from an economic and thermodynamic viewpoint. A recent comparison of indirect and direct gasification for Bio-SNG production with different options for converting the process excess heat to electrical power indicates that $\mathrm{O}_{2}$-blown gasification is slightly more advantageous considering exergetic and economic efficiency, but that indirect gasification is more favourable with respect to carbon footprint evaluation measured as emission of $\mathrm{CO}_{2}$-equivalents per $\mathrm{MJ}_{\mathrm{SNG}}$ produced [9]. Finally, a comparison for coal to $\mathrm{SNG}$ production [10] states that indirect gasification has both a higher energy and exergy efficiency than direct $\mathrm{O}_{2^{-}}$ blown gasification for a process with a thermal input of $5 \mathrm{MW}_{\mathrm{LHV}}$. Most system studies use experimental data regression of a specific experimental dataset derived from equipment ranging from lab to pilot scale. This regression implies the risk of intrinsically favouring a certain gasification technology as experimental conditions between different types of equipment vary considerably. Energy efficiency calculations accounting for different energy forms (fuel, electricity, heat) are difficult to compare between different studies as there is currently no common agreement on how to weigh different forms of energy in such calculations. Exergy analysis in contrast is a rigorous way of combining first and second law of thermodynamics with the ambient conditions being the main reference point, allowing for a more transparent comparison of different technologies.

The aim of this paper is to present a clear picture of the difference in performance for the two different gasification technologies based on an exergy analysis approach and using a simplified gasification reaction scheme. The major parameter investigated is the pressure of the product gas at the inlet of the methanation section. Varying both $\mathrm{H}_{2} / \mathrm{CO}$ ratio and the air-to-fuel ratio $\lambda$ for the gasification as additional parameters, an indepth comparison is achieved. In order to reduce the influence of specific differences concerning reactor design and operating conditions (such as bed material choice) on the comparison, a simple stoichiometric model for the gasification step is used. This allows the two gasification technologies to be compared on a common basis. Starting from an ideal process, the inherent exergy losses are illustrated and thereafter technological constraints are considered so as to identify the major technical sources of efficiency losses for the two technologies. Based on the results obtained, possible process improvements and technical barriers for the two gasification technologies in the framework of Bio-SNG production are thereafter discussed. 
The final publication is available at http://link.springer.com/article/10.1007/s13399-013-0079-1. Published in Biomass Conversion and Biorefinery 2013, DOI: 10.1007/s13399-013-0079-1

\section{Methodology}

\subsection{System definition}

The two gasification systems are compared on the same basis within the Bio-SNG production process focusing on the conversion of solid fuel to a clean product gas ready for downstream conversion to methane. The biomass feed considered in this study is a generic biomass containing no ash and moisture with a composition as defined in Table 1.

Table 1: Biomass composition and heating value.

\begin{tabular}{cc} 
Biomass composition & [weight-\%] \\
\hline $\mathrm{C}$ & 50 \\
$\mathrm{H}$ & 6 \\
$\mathrm{O}$ & 44 \\
Biomass heating value & {$[\mathbf{M J} / \mathbf{k g}]$} \\
\hline $\mathrm{HHV}$ & $19.98^{a}$ \\
$\mathrm{LHV}$ & $18.67^{b}$ \\
Biomass exergy value & {$[\mathbf{M J} / \mathbf{k g}]$} \\
\hline$e_{\text {biomass }}{ }^{a}$ Based on Channiwala \& Parikh $[11]$ \\
${ }^{b} \mathrm{LHV}[\mathrm{MJ} / \mathrm{kg}]=\mathrm{HHV}[\mathrm{MJ} / \mathrm{kg}]-2.44 \cdot 8.94 \cdot \mathrm{H}[\mathrm{wt}-\%] / 100$ \\
${ }^{c}$ Factor between exergy value and HHV of 1.06 based on Szargut $[12]$
\end{tabular}

Figure 1 illustrates the general set-up for a biomass to SNG process and the boundary limits for the comparison of the two gasification technologies adopted in this study.

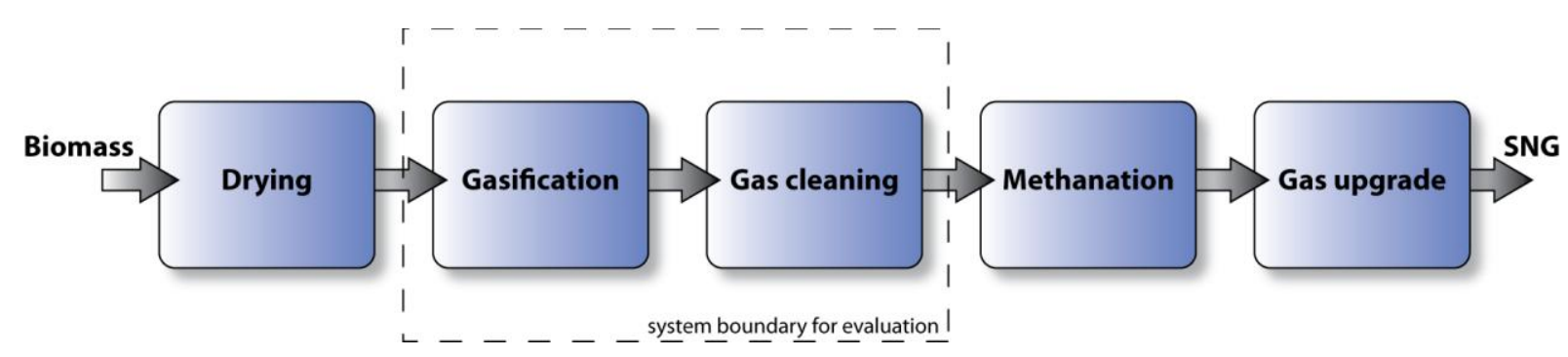

Figure 1: Bio-SNG process with indication of system boundaries for this study.

Prior to gasification a drying step reduces the moisture content of the incoming biomass. In the current study the effect of varying moisture on the exergetic efficiency is not assessed but dry and ash-free biomass assumed as input to the gasification unit. The effects of drying the gasification feedstock can be expected to be similar for indirect and direct gasification with lower moisture content leading to a higher exergetic efficiency of the gasification process [13]. The clean product gas resulting from gasification is converted to methane in a synthesis step and has to be cleaned from $\mathrm{CO}_{2}$ and residual moisture in order to comply with natural gas standards. Commercially available methanation technologies were originally developed for coal to SNG processes. Fixed bed methanation in a series of intercooled reactors at higher pressure is state-of-the art [14]. Even fluidised bed technology has been developed for methanation [15] and further developed specifically for methanation of product gas from biomass gasification [16] but no industrial scale technology development has been achieved so far. The two main reactions forming methane from product gas are:

$$
\begin{array}{ll}
\mathrm{CO}+3 \mathrm{H}_{2} \leftrightarrow \mathrm{CH}_{4}+\mathrm{H}_{2} \mathrm{O} & \Delta H_{r}^{29815 \mathrm{~K}}=-205.9 \mathrm{~kJ} / \mathrm{mol} \\
\mathrm{CO}_{2}+4 \mathrm{H}_{2} \leftrightarrow \mathrm{CH}_{4}+2 \mathrm{H}_{2} \mathrm{O} & \Delta H_{r}^{29815 \mathrm{~K}}=-164.8 \mathrm{~kJ} / \mathrm{mol}
\end{array}
$$

The conversion of carbon dioxide to methane (eq. 2) is actually a combination of eq. 1 and the reverse water gas shift reaction and only occurs to a very limited degree as high levels of hydrogen are necessary. In common 
industrial methanation processes - such as the TREMP process by Haldor Topsøe implemented in the GoBiGas project - most of the $\mathrm{CO}_{2}$ is separated from the product gas prior to methanation [1]. As indicated by the stoichiometry of eqs. 1 and 2, increased pressure favours the methane yield according to Le Chatelier's principle. The delivery pressure of the product gas fed to the methanation section is varied from 1 to 30 bar as one of the major parameters investigated in this study. The $\mathrm{CO}_{2}$ content of the clean product gas and the consequences for downstream separation demands or opportunities for increased methane generation are also discussed. In addition to variation of the pressure, the impact of $\mathrm{H}_{2} / \mathrm{CO}$ ratio of the resulting product gas and the relative airto-fuel ratio $\lambda$ (in the range from 0.3 to 0.4 ) are also investigated. This choice of operating parameters is mainly aimed at achieving good comparability of the results. The aim of the study is not to determine optimum operating conditions but rather to identify fundamental differences in impact on performance of key process conditions for both gasification technologies.

\subsection{Gasification modelling}

In order to exclude effects of equipment specific differences between the two technologies on the results, the gasification process is modelled using a simplified stoichiometric model accounting for five species only: $\mathrm{CO}$, $\mathrm{H}_{2}, \mathrm{CH}_{4}, \mathrm{CO}_{2}$, and $\mathrm{H}_{2} \mathrm{O}$. The conversion of biomass to product gas in the gasification step is a very complex process depending on numerous parameters. Published data on gas yield and composition differs significantly even for a single gasification technology. For example, Hannula [17] reports carbon conversions close to $100 \%$ for direct oxygen-blown gasification and product gas composition at equilibrium with regard to the water gas shift reaction whereas Siedlecki and de Jong [18] present experimental results with carbon conversion in the range of $65-90 \%$ and a product gas composition far from equilibrium with respect to WGS. Even effects of pressurisation on the product gas composition are difficult to model as little experimental data (e.g. Kitzler [19], Puchner [20], Valin [21]) is published and data trends are not consistent. Based on the previously mentioned studies [19-21], an increase in $\mathrm{CH}_{4}$ and $\mathrm{CO}_{2}$ concentration and a decrease in $\mathrm{CO}$ concentration can be identified as general trends. As no reliable correlation of general character can be derived from the data, the effect of pressure on the gas composition is not taken into account in the current study. It can be assumed that pressurisation effects will result in similar changes for both indirect and direct gasification as the chemical environments are comparable. The simplified reaction scheme for determining the product gas composition is illustrated in Figure 2. The decomposition of the biomass fraction entering the gasifier is maximised so as to favour $\mathrm{CO}$ yield. After potential steam reforming of the $\mathrm{CH}_{4}$ present by addition of steam, a gas composition with maximum $\mathrm{CO}$ concentration (case $\mathrm{CO}$ max) is obtained. By further addition of water for a complete water gas shift reaction, it is possible to gradually increase the $\mathrm{H}_{2} / \mathrm{CO}$ ratio of the product gas with the limiting case corresponding to all $\mathrm{CO}$ being converted to $\mathrm{H}_{2}$ (case $\mathrm{H}_{2}$ max). The aim of this major simplification is to reduce effects of e.g. different bed materials and reactor setups on the comparability of the two technologies that might otherwise result in a biased comparison of the two gasification technologies. Carbon conversion is assumed to be complete in both cases. The effect of carbon conversion during gasification will be discussed on a qualitative basis in the results section. 


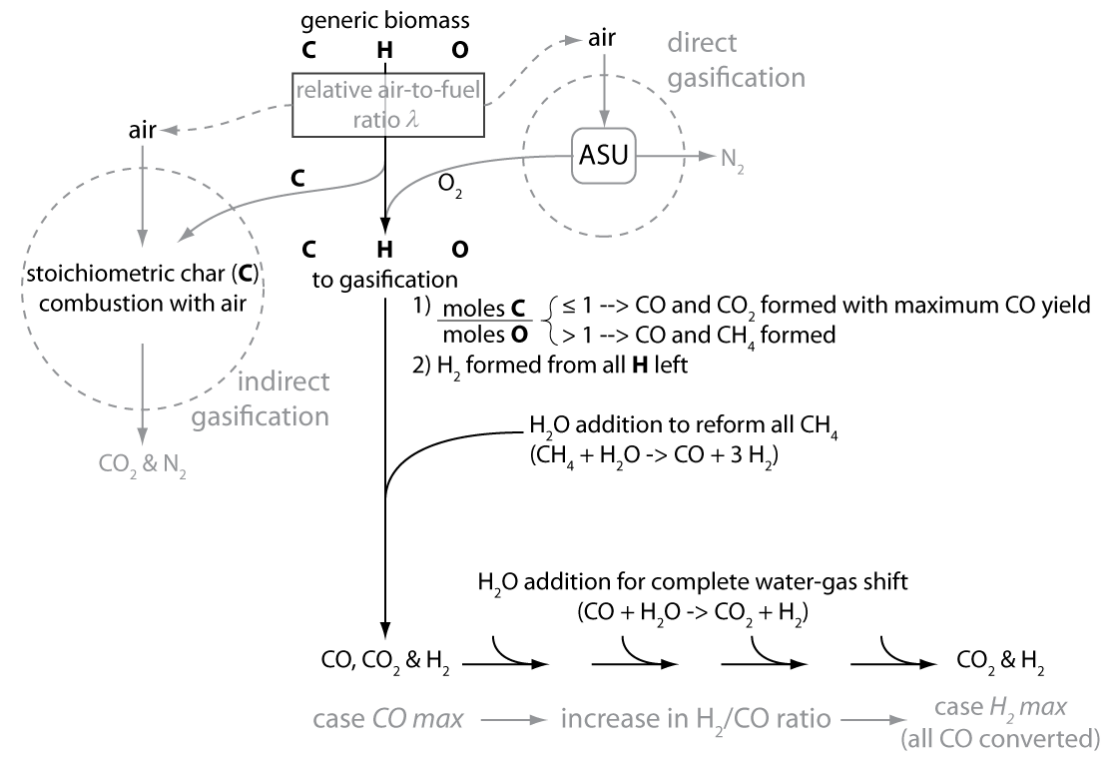

Figure 2: Simplified reaction scheme used for gasification modelling.

\subsection{Process setup for ideal gasification systems}

The two gasification concepts are compared using an exergy-based approach. The exergy content of the streams entering and leaving the system are related to each other in order to quantify the inherent losses for the two concepts at different operating conditions. For both systems, the oxidising agents (air, steam, or oxygen) are assumed to be supplied at $300{ }^{\circ} \mathrm{C}$. The basic setup is illustrated in Figure 3 for the indirect gasification concept, including an atmospheric process with final compression to the specified delivery pressure. The direct gasification is assumed to be pressurised with all streams being supplied at the specified pressure. In addition, for the ideal system comparison, atmospheric direct gasification with subsequent compression of the product gas as well as pressurised indirect gasification were investigated.
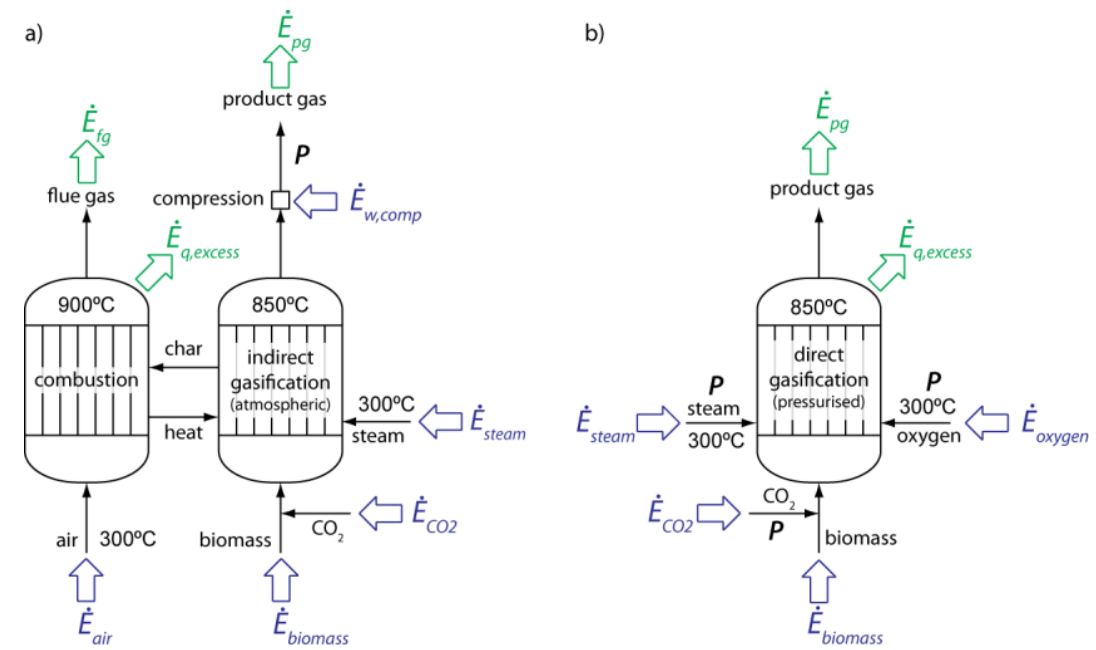

Figure 3: Indirect (a) and direct (b) gasification - Ideal system definition and exergy streams accounted for in efficiency calculations.

The exergy efficiency of the ideal system $\eta_{\text {ex,ideal }}$ relates the combined exergy flows of all resulting output streams to combined exergy flows of the input streams as defined in eq. (3). The exergy flow $\dot{E}_{i}$ of each material stream $i$ is based on the sum of the physical and chemical exergies according to the methodology proposed by Szargut [12] using atmospheric conditions as reference state (298.15 K, 1.01325 bar). For heat 
streams, the exergy flow $\dot{E}_{q, i}$ is related to the energy flow using the Carnot factor and for work streams, the exergy flow $\dot{E}_{w, i}$ is equal to the energy flow.

$$
\eta_{\text {ex,ideal }}=\frac{\dot{E}_{p g}+\dot{E}_{f g}+\dot{E}_{q, \text { excess }}}{\dot{E}_{\text {biomass }}+\dot{E}_{\text {air/oxygen }}+\dot{E}_{C O 2}+\dot{E}_{\text {steam }}+\dot{E}_{w, \text { comp }}}
$$

\subsection{Process setup for gasification system including losses}

In a further step, the two gasification concepts are investigated with respect to their performance in systems including losses, i.e. accounting for losses associated with heat exchange, compression, as well as supply of feed streams. The process performance and the losses occurring in the auxiliary systems are again quantified using exergy analysis. The excess heat from gas cooling and available excess heat from the gasification process are assumed to be used for generation of high pressure superheated steam from feedwater as well as district heat generation. It is assumed that steam generation is possible without restrictions and the gas cleaning section is simply represented as pressure losses. In reality product gas from biomass gasification requires substantial treatment for particle and tar removal as well as removal of trace substances such as sulphur compounds (mainly $\mathrm{H}_{2} \mathrm{~S}$ and COS) and ammonia. For the thermal efficiency of the process tars are the most important problem to solve as they represent a significant amount of the product gas energy content even though their mass fraction is rather low. For example for indirect gasification without any primary measures for tar reduction (e.g. by using catalytic bed material) the tar content can be in the range of $30 \mathrm{~g} / \mathrm{Nm}^{3}$ dry gas, corresponding to about $8 \%$ of the chemical energy content of the dry gas on a LHV basis [22]. For atmospheric indirect gasification a cold gas cleaning section with a scrubber using oil or water removing the tars is common practice [23,24]. This puts some penalty on the heat recovery from the product gas as the gas only can be cooled down to a certain temperature prior to scrubbing. For pressurised oxygen-blown gasification hot gas cleaning is the commonly proposed technology with all sensible heat from the product gas being available for heat recovery. Tar reforming is a very versatile process that can be tailored for the specific application by choosing the active catalyst. For Bio-SNG production it is desirable to have a catalyst that is active for tar reforming without catalysing reforming of the methane present in the product gas. Tar reforming of product gas from biomass gasification is still at the research stage but very promising results have been published $[25,26]$. The simplified representation of the gas cleaning chain in this study again aims at comparing the two systems on a common basis. The indirect gasification concept is assumed to have a cold gas cleaning chain consisting of a filter and a scrubber while the pressurised direct gasification system is based on a high temperature tar reformer and a filter enabling hot gas cleaning. The two gas cleaning concepts can in principle be applied to either of the gasification concepts as will be taken up in the discussion section of the paper.

Figure 4 shows the overall setup for atmospheric indirect gasification and pressurised gasification including gas cleaning considered in this study as well as the system boundary and streams accounted for in the efficiency calculations. 

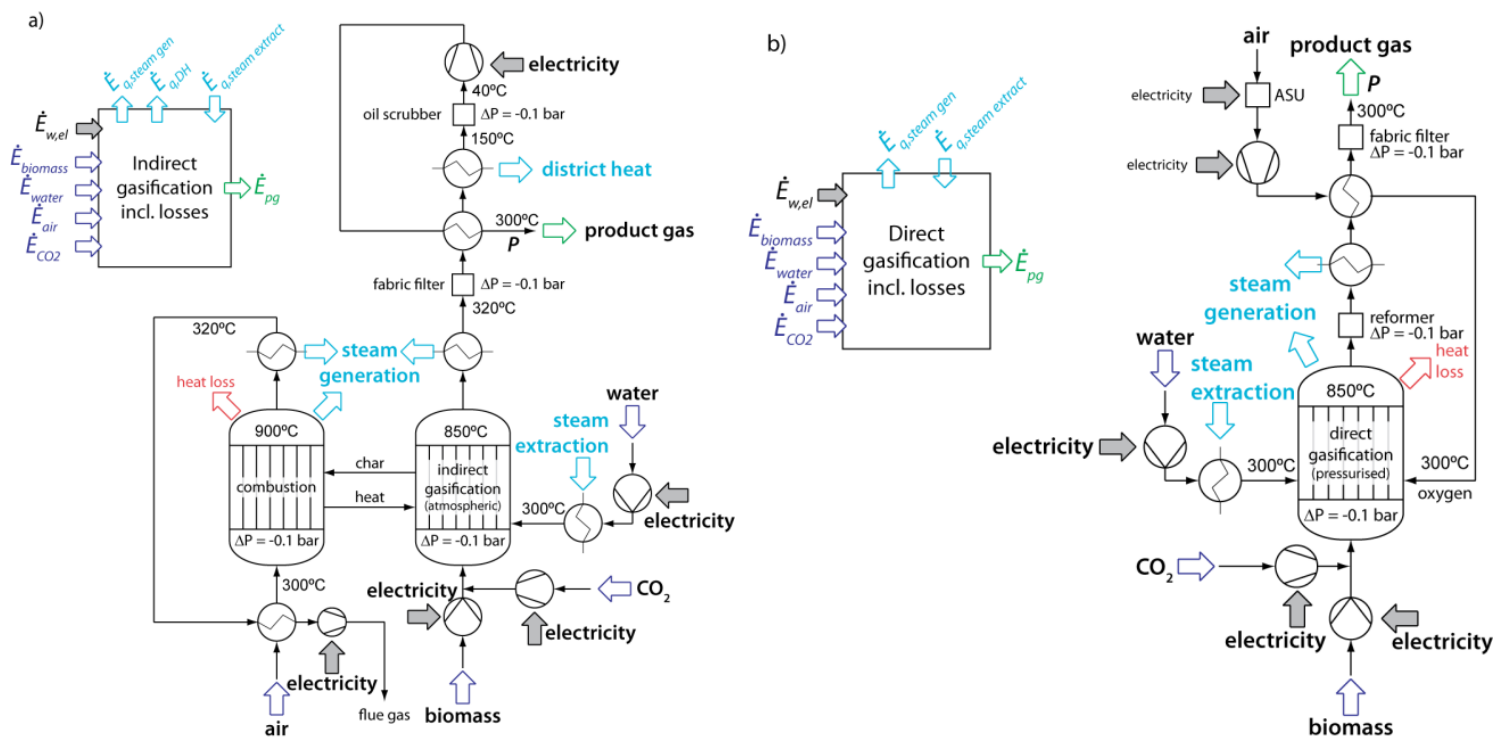

Figure 4: Indirect (a) and direct (b) gasification - system definition and associated exergy streams accounted for in efficiency calculations accounting for losses according to eq. (4).

The exergy efficiency of the system including losses $\eta_{e x, l o s s e s}$ again relates system output to input according to eq. 4:

$$
\eta_{\text {ex,loss }}=\frac{\dot{E}_{p g}+\dot{E}_{q, \text { steamgen }}+\dot{E}_{q, D H}}{\dot{E}_{\text {biomass }}+\dot{E}_{\text {air }}+\dot{E}_{C O 2}+\dot{E}_{\text {water }}+\dot{E}_{w, e l}+\dot{E}_{q, \text { steamextrat }}}
$$

Table 2 illustrates the process parameters for the two gasification concepts as well as the high pressure steam data and district heating water conditions assumed. The latter are based on data for a generic biomass-based combined heat and power plant with a thermal boiler load of $80 \mathrm{MW}_{\text {th,LHV }}$ [27]. The thermodynamic state of the steam extracted for heating the gasification steam is determined by assuming that high pressure steam is used with given expansion characteristics, as listed in the table. The pressure level is adjusted to ensure a minimum temperature difference between the hot and cold stream of $10 \mathrm{~K}$ with the extraction steam being cooled to saturated liquid state. 
The final publication is available at http://link.springer.com/article/10.1007/s13399-013-0079-1. Published in Biomass Conversion and Biorefinery 2013, DOI: 10.1007/s13399-013-0079-1

Table 2: Basic assumptions for gasification processes and the associated heat recovery and cogeneration system.

\begin{tabular}{|c|c|c|c|c|c|}
\hline & \multicolumn{2}{|c|}{ Indirect gasification } & \multicolumn{2}{|c|}{ Direct gasification } \\
\hline & & Ideal & Incl. losses & Ideal & Incl. losses \\
\hline Temperature & {$\left[{ }^{\circ} \mathrm{C}\right]$} & \multicolumn{2}{|c|}{900 (combustion) / 850 (gasification) } & \multicolumn{2}{|c|}{850} \\
\hline Pressure drop & [bar] & 0 & 0.1 & 0 & 0.1 \\
\hline Steam preheat & {$\left[{ }^{\circ} \mathrm{C}\right]$} & \multicolumn{2}{|c|}{300} & \multicolumn{2}{|c|}{300} \\
\hline $\begin{array}{l}\text { medium } \\
\text { preheat }\end{array}$ & {$\left[{ }^{\circ} \mathrm{C}\right]$} & \multicolumn{2}{|c|}{300} & \multicolumn{2}{|c|}{300} \\
\hline Heat loss & - & 0 & $\begin{array}{c}2 \% \text { of thermal } \\
\text { LHV input }\end{array}$ & 0 & $\begin{array}{c}2 \% \text { of thermal } \\
\text { LHV input }\end{array}$ \\
\hline \multicolumn{2}{|l|}{$\begin{array}{l}\text { high pressure } \\
\text { steam data }\end{array}$} & \multicolumn{4}{|c|}{$\begin{array}{l}\text { ·pressure: } 122 \text { bar } \\
\text { superheating temperature: } 520^{\circ} \mathrm{C}\end{array}$} \\
\hline \multicolumn{2}{|l|}{$\begin{array}{l}\text { District heat } \\
\text { data }\end{array}$} & \multicolumn{4}{|c|}{$\begin{array}{c}\cdot \text { pressure: } 6 \text { bar } \\
\cdot \mathrm{T}_{\mathrm{DH} \text {,return }}=45^{\circ} \mathrm{C} \\
\cdot \mathrm{T}_{\mathrm{DH} \text {,hot }}=90^{\circ} \mathrm{C}\end{array}$} \\
\hline \multicolumn{2}{|l|}{$\begin{array}{c}\text { Steam } \\
\text { extraction }\end{array}$} & \multicolumn{4}{|c|}{$\begin{array}{c}\text { - turbine isentropic efficiency: } 0.8 \\
\text { - extraction steam cooled down to saturated liquid } \\
\text { - extraction pressure level set to assure minimum temperature difference of } 10 \mathrm{~K} \\
\text { between extraction steam and heated stream }\end{array}$} \\
\hline
\end{tabular}

\subsection{Auxiliary system modelling assumptions}

Feeding of solid biomass into the gasification reactor is often the most critical process step during gasification. A continuous and uniform feed to the gasifier is a central aspect in ensuring reliable operation of biomass gasification systems [28]. A number of different feeding technologies for biomass are available with lock-hopper systems and piston feeders being the most mature systems that are available at large scale and allow for pressurisation $[29,28]$. The most commonly used feeding system is a lock-hopper system with feeding screws as proposed by e.g. TR Miles [30]. The major performance parameters of the feeding system are the amount of inert gas that is needed and the electric power consumption. The void fraction of the bulky feed material has to be filled with inert gas (e.g. $\mathrm{N}_{2}$ or $\mathrm{CO}_{2}$ ) to avoid entrainment of air into the gasification reactor. Increasing pressure of the reactor will increase the amount of inert gas necessary and consequently the amount of inert gases entering the gasifier with the feed material.

Given the effective solid volume fraction in the feeding system $\varphi$ and the density of the feed material $\rho_{f}$, as well as the pressure level $P$ of the feeding system, the theoretically necessary mass flow of inert gas $\dot{m}_{\text {inert }}$ can be estimated using the ideal gas law.

$$
\dot{m}_{\text {inert }}=\frac{(1-\varphi)}{\rho_{f} \cdot \varphi} \cdot \frac{P \cdot M}{R \cdot T} \cdot m_{f}
$$

$M, R$, and $T$ denote the molar weight of the inert gas, the gas constant, and the temperature in the feeding system, respectively, and $\dot{m}_{f}$ denotes the solid feed material mass flow.

Direct $\mathrm{O}_{2}$-blown gasification requires an air-separation unit (ASU) for providing pure oxygen for the gasification reactor. For large scale applications, cryogenic ASU is the most common technology and in connection to integrated gasification combined cycles (IGCC) the process has been optimised with significant reductions in 
power consumption due to tight integration of the processes [31]. In this work we assume standard ASU technology with an energy consumption of $882 \mathrm{~kJ} / \mathrm{kg} \mathrm{O}_{2}\left(245 \mathrm{kWh} / \mathrm{t} \mathrm{O}_{2}\right)$ [32] delivering oxygen at 1.15 bar and a final compression of the oxygen to a pressure above the gasification pressure level. This specific power consumption is somewhat higher compared to published ASU data for IGCC or oxy-fuel combustion applications (e.g. $720 \mathrm{~kJ} / \mathrm{kg} \mathrm{O}_{2}$ [33]). This is because the $\mathrm{O}_{2}$-purity needed in biomass gasification for fuel production is higher and no process integration benefits between the ASU and the biofuel synthesis process can be expected, as stated by Gassner [8]. This implies that neither integration of the ASU compressors nor low temperature cooling can be provided by the biofuel synthesis process. In the models, it is assumed that the ASU delivers pure $\mathrm{O}_{2}$ to the gasifier reactors.

The compressors assumed in the process models are multistage compressors with intercooling and a maximum compression ratio of 4. Aspen Plus [34] flowsheeting software was used for all simulations using the PengRobinson equation of state for thermodynamic property calculations of all gaseous streams and steam table data for water streams. A summary of the auxiliary system simulation assumptions is given in Table 3.

Table 3: Simulation assumptions for auxiliary systems.

\begin{tabular}{cccc} 
Property & Symbol & Value & Unit \\
\hline effective solid volume fraction & $\varphi^{a}$ & 0.15 & - \\
feed material density & $\rho_{f}$ & 500 & $\mathrm{~kg} / \mathrm{m}^{3}$ \\
inert gas molar weight $\left(\mathrm{CO}_{2}\right)$ & $M$ & 44 & $\mathrm{~g} / \mathrm{mol}$ \\
feeding system temperature & $T$ & 40 & ${ }^{\circ} \mathrm{C}$ \\
feeding screw power consumption ${ }^{b}$ & $w_{\text {screw }}$ & 7 & $\mathrm{~kJ} / \mathrm{kg}$ \\
ASU specific electricity demand & $w_{A S U}$ & 882 & $\mathrm{~kJ} / \mathrm{kg} \mathrm{O}_{2}$ \\
ASU oxygen delivery pressure & $P_{A S U}$ & 1.15 & $\mathrm{bar}$ \\
maximum compression ratio per compressor stage & $\Pi_{\text {max }}$ & 4 & - \\
compressor isentropic efficiency & $\eta_{\text {is, comp }}$ & 0.8 & - \\
compressor intercooling temperature & $T_{\text {intcool }}$ & 40 & ${ }^{\circ} \mathrm{C}$ \\
pump efficiency & $\eta_{\text {pump }}$ & varying ${ }^{c}$ & \\
\hline${ }^{a}$ assuming a void fraction for the biomass feed material bulk of 0.5 (bulk density in the range of \\
250 kg/m ${ }^{3}\left[35\right.$ ] and material density 500 kg/m ${ }^{3}[36]$ and a filling degree for the feeding screw \\
of $30 \%$ [37] \\
${ }^{b}$ based on [38] \\
${ }^{c}$ based on efficiency curve for water [34]
\end{tabular}

\subsection{Additional performance indicators}

In order to be able to compare the two gasification technologies, a number of additional performance indicators in addition to the exergy efficiency are required. A common indicator for gasification performance is the cold gas efficiency $\eta_{c g}$ relating the thermal input in form of fuel to the chemical energy content in the product gas:

$$
\eta_{c g}=\frac{\dot{m}_{p g} \cdot L H V_{p g}}{\dot{m}_{\text {fuel }} \cdot L H V_{\text {fuel }}}
$$

The product gas heating value $L H V_{p g}$ is the sum of products of mass fraction and mass-specific lower heating value of the combustible components present in the product gas.

For further treatment of the product gas for production of Bio-SNG, the amount and concentration of $\mathrm{CO}_{2}$ can be used as an indicator of downstream upgrade energy demands. Assuming that $\mathrm{CO}_{2}$ is not participating in the methanation reactions but needs to be separated from the product gas, an energy or exergy penalty can be determined assuming complete separation of $\mathrm{CO}_{2}$ with e.g. amine-based absorption. The exergy efficiency defined in eq. (4) will thus be reduced as an additional term representing the exergy input for $\mathrm{CO}_{2}$ separation will figure in the denominator. The exergy efficiency $\eta_{\text {ex,loss } \mathrm{CO} 2}$ accounting for the $\mathrm{CO}_{2}$ separation penalty can thus be defined according to: 
The final publication is available at http://link.springer.com/article/10.1007/s13399-013-0079-1. Published in Biomass Conversion and Biorefinery 2013, DOI: 10.1007/s13399-013-0079-1

$$
\eta_{\text {ex,loss CO2 }}=\frac{\dot{E}_{p g}+\dot{E}_{q, \text { steamgen }}+\dot{E}_{q, D H}}{\dot{E}_{\text {biomass }}+\dot{E}_{\text {air }}+\dot{E}_{C O 2}+\dot{E}_{\text {water }}+\dot{E}_{w, e l}+\dot{E}_{q, \text { steamextrat }}+\dot{E}_{C O 2 s e p}}
$$

The exergy demand for the $\mathrm{CO}_{2}$ separation can be determined according to

$$
\dot{E}_{\mathrm{CO} 2 \mathrm{sep}}=\dot{m}_{\mathrm{CO} 2} \cdot e_{\mathrm{CO} 2 \mathrm{sep}}
$$

$\dot{m}_{\mathrm{CO} 2}$ is the mass flow of $\mathrm{CO}_{2}$ in the product gas and $e_{\mathrm{CO} 2 \mathrm{sep}}$ the specific exergy demand of $0.975 \mathrm{MJ} / \mathrm{kg} \mathrm{CO}_{2}$ assuming amine based adsorption with a specific heat energy demand of $3.3 \mathrm{MJ} / \mathrm{kg} \mathrm{CO}_{2}$ at $150^{\circ} \mathrm{C}$ [39] for separation. It has to be mentioned that the definition of eq. (7) gives approximate values for the exergy efficiency penalty associated to $\mathrm{CO}_{2}$ separation only as more streams would need to be accounted for when extending the system boundaries to $\mathrm{CO}_{2}$ separation. For the scope of this study and the way eq. (7) is used in the discussion of the results, this approach is considered sufficiently detailed, however.

Finally the specific electricity consumption per product gas fuel energy produced $w_{\text {gasif }}$ can be calculated adding an additional dimension to the comparison of the two processes:

$$
w_{\text {gasif }}=\frac{\dot{W}_{e l}}{\dot{m}_{p g} \cdot L H V_{p g}}
$$

The consumption $w_{\text {gasif }}$ then can be analysed in relation to the specific exergy output $w_{\text {steam }}$ to the cogeneration steam cycle:

$$
w_{\text {steam }}=\frac{\dot{E}_{q, \text { steamgen }}-\dot{E}_{q, \text { steamextrat }}}{\dot{m}_{p g} \cdot L H V_{p g}}
$$

\section{Results}

\subsection{Ideal gasification system analysis}

As neither pressure nor temperature dependence of the gas composition is implemented in the model, the product gas yield is constant over the pressure range investigated. Due to the model structure, the combustible components composition is similar for both gasification technologies for a given combination of relative air-tofuel ratio $\lambda$ and $\mathrm{H}_{2} / \mathrm{CO}$ ratio. However, at low $\lambda$ values (e.g. $\lambda=0.3$ at $C O$ max), the composition may differ as the carbon stock entering the indirect gasifier may exceed the oxygen stock, resulting in methane formation and subsequent reforming with steam. For direct gasification, methane formation only occurs at very low $\lambda$ values based on the stoichiometric model used. The resulting cold gas efficiency for the parameter range investigated is given in Table 4. It should be noted that $\eta_{c g}$ has the same values for the pressurised and atmospheric gasification technologies and is also the same for the cases including losses. An increase in the relative air-to-fuel ratio $\lambda$ obviously leads to a lower cold gas efficiency since more fuel is burnt. Increased $\mathrm{H}_{2} / \mathrm{CO}$ ratio in the product gas also leads to a decrease in the cold gas efficiency due to the exothermal nature of the water gas shift reaction which converts $\mathrm{CO}$ to $\mathrm{H}_{2}$ with steam that is added to the gasifier, thereby reducing the chemical energy content of the product gas. 
The final publication is available at http://link.springer.com/article/10.1007/s13399-013-0079-1. Published in Biomass Conversion and Biorefinery 2013, DOI: 10.1007/s13399-013-0079-1

Table 4: Cold gas efficiency $\eta_{c g}$ for both gasification processes at varying air-to-fuel and $\mathrm{H}_{2} / \mathrm{CO}$ ratio.

\begin{tabular}{cccc} 
& \multicolumn{3}{c}{ relative air-to-fuel ratio $\boldsymbol{\lambda}$} \\
$\mathbf{H}_{2} / \mathbf{C O}$ ratio & $\mathbf{0 . 3}$ & $\mathbf{0 . 3 5}$ & $\mathbf{0 . 4}$ \\
\hline $\boldsymbol{C O}$ max $^{\mathbf{a}}$ & $0.839 / 0.842^{b}$ & 0.777 & 0.712 \\
$\mathbf{2}$ & 0.820 & 0.761 & 0.702 \\
$\mathbf{3}$ & 0.809 & 0.751 & 0.693 \\
$\boldsymbol{H}_{2}$ max & 0.776 & 0.720 & 0.665
\end{tabular}

${ }^{a}$ The actual $\mathrm{H}_{2} / \mathrm{CO}$ ratio for the three $\lambda$ values are 0.3: $1.08 / 0.99,0.35: 1.15$, and 0.4: 1.38 .

${ }^{b}$ Lower $\eta_{c g}$ for indirect gasification as steam added for methane reforming (see Figure 2).

It can be observed that the exergy efficiency of the ideal systems $\eta_{\text {ex,ideal }}$ is virtually constant for both direct and indirect gasification operating at atmospheric conditions. Pressurised systems show increased exergy efficiency at higher pressures and indirect gasification even outperforms direct gasification for the ideal case. The increase in exergy efficiency between atmospheric and pressurised operation is about $2 \%$-points for direct gasification and 3-\% points for indirect gasification at the highest pressure level of 30 bar investigated. Figure 5 illustrates two examples of the variation of exergy efficiency with increasing pressure at $\lambda=0.35$. The representation on a $\mathrm{y}$-scale starting at zero is used to illustrate the small difference between the two gasification technologies on an absolute scale. The largest gain in exergy efficiency is achieved at moderate pressurisation levels of 5-10 bar while a further increase only yields rather small benefits.
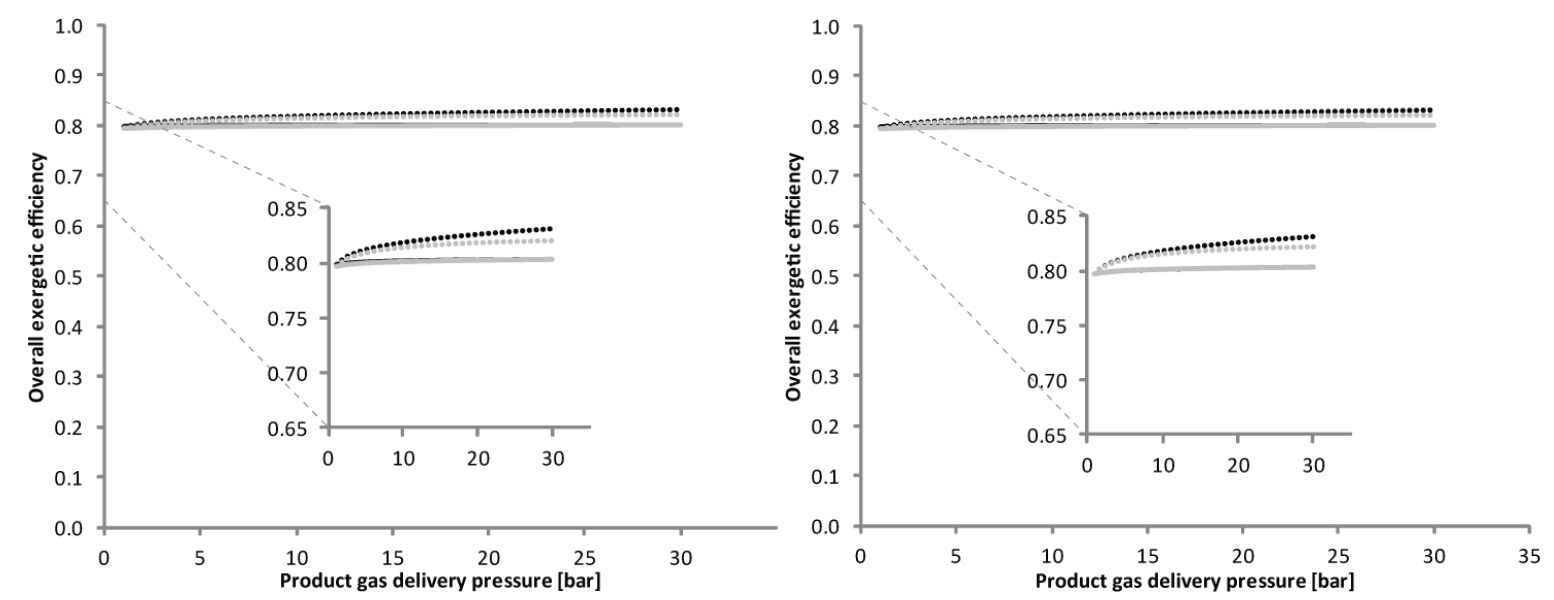

Figure 5: Exergy efficiency of ideal systems at $\lambda=0.35$ for two $\mathrm{H}_{2} / \mathrm{CO}$ ratios (left: $\mathrm{H} 2 / \mathrm{CO}=2$, right H2/CO = 3).black lines - indirect gasification, grey lines - direct gasification, solid lines - atmospheric, dashed lines - pressurised.

Table 5 gives the minimum (at atmospheric pressure) and maximum (at 30 bar) exergetic efficiencies for the ideal systems for a $\mathrm{H}_{2} / \mathrm{CO}$ ratio of 3 . Varying the $\mathrm{H}_{2} / \mathrm{CO}$ ratio has a negligible effect on the exergy efficiency for all technology alternatives and air-to-fuel ratios with a maximum relative difference between the two extreme cases $\mathrm{CO}$ max and $\mathrm{H} 2$ max of less than $0.5 \%$. It is shown that increasing the air-to-fuel ratio leads to a decrease in exergetic performance but the influence is less pronounced than on the cold gas efficiency $\eta_{c g}$. 
The final publication is available at http://link.springer.com/article/10.1007/s13399-013-0079-1. Published in Biomass Conversion and Biorefinery 2013, DOI: 10.1007/s13399-013-0079-1

Table 5: Minimum (at 1 bar) and maximum (at 30 bar) exergy efficiency $\eta_{e x, \text { ideal }}$ of the ideal systems for $\mathrm{H}_{2} / \mathrm{CO}=3$.

Exergy efficiency $\eta_{\text {ex,ideal }}$ for ideal systems ( $\min / \max$ )

\begin{tabular}{|c|c|c|c|c|c|c|c|c|}
\hline \multirow{3}{*}{$\lambda$} & \multicolumn{4}{|c|}{ indirect gasification } & \multicolumn{4}{|c|}{ direct gasification } \\
\hline & \multicolumn{2}{|c|}{ atmospheric } & \multicolumn{2}{|c|}{ pressurised } & \multicolumn{2}{|c|}{ atmospheric } & \multicolumn{2}{|c|}{ pressurised } \\
\hline & $\min ^{a}$ & $\max ^{b}$ & $\min ^{a}$ & $\max ^{b}$ & $\min ^{a}$ & $\max ^{b}$ & $\min ^{a}$ & $\max ^{b}$ \\
\hline 0.3 & $80.7 \%$ & $81.2 \%$ & $80.7 \%$ & $84.1 \%$ & $80.5 \%$ & $81.2 \%$ & $80.5 \%$ & $83.0 \%$ \\
\hline 0.35 & $79.7 \%$ & $80.3 \%$ & $79.8 \%$ & $83.2 \%$ & $79.6 \%$ & $80.3 \%$ & $79.6 \%$ & $82.1 \%$ \\
\hline 0.4 & $78.8 \%$ & $79.3 \%$ & $\begin{array}{r}78.9 \% \\
{ }^{a} \text { at } 1 b\end{array}$ & $82.2 \%$ & $\begin{array}{l}78.7 \% \\
30 \mathrm{bar}\end{array}$ & $79.4 \%$ & $78.7 \%$ & $81.2 \%$ \\
\hline
\end{tabular}

\subsection{Gasification systems including losses}

For the systems including losses the cold gas efficiency is similar to the ideal cases (see Table 4) as the reaction scheme applied is the same. The exergy efficiency in contrast is lower as heat losses and losses due to heat transfer, compression, and pressure drop are accounted for. Table 6 presents the minimum and maximum exergetic efficiencies. Even here the relative difference in exergetic efficiency between different $\mathrm{H}_{2} / \mathrm{CO}$ ratios is small (below 3\%) but a more pronounced influence compared to the ideal systems can be observed. For atmospheric indirect gasification this is partly due to the higher amount of product gas to be compressed, putting a penalty on the exergy efficiency. For both technologies, increased steam extraction for preheating the steam for gasification at higher $\mathrm{H}_{2} / \mathrm{CO}$ ratios puts a penalty on the exergy efficiency. For a given air-to-fuel ratio and $\mathrm{H}_{2} / \mathrm{CO}$ ratio, indirect gasification basically shows an exergy efficiency that is highest at 1 bar and decreases marginally with pressure. Direct gasification benefits from pressurisation with an increase of more than two $2 \%$ points over the whole parameter range (from 1 bar to 30 bar).

Table 6: Minimum and maximum exergy efficiency $\eta_{e x, l o s s}$ of the systems including losses.

\begin{tabular}{|c|c|c|c|c|c|}
\hline \multicolumn{6}{|c|}{ Exergy efficiency $\eta_{\text {ex,loss }}$} \\
\hline \multirow{2}{*}{$\lambda$} & \multirow{2}{*}{$\mathrm{H}_{2} / \mathrm{CO}$ ratio } & \multicolumn{2}{|c|}{$\begin{array}{l}\text { indirect gasification } \\
\text { atmospheric }\end{array}$} & \multicolumn{2}{|c|}{$\begin{array}{l}\text { direct gasification } \\
\text { pressurised }\end{array}$} \\
\hline & & $\min ^{b}$ & $\max ^{a}$ & $\min ^{a}$ & $\max ^{b}$ \\
\hline \multirow{4}{*}{0.3} & $C O \max$ & $76.1 \%$ & $76.6 \%$ & $76.7 \%$ & $78.9 \%$ \\
\hline & 2 & $75.3 \%$ & $75.7 \%$ & $75.9 \%$ & $78.5 \%$ \\
\hline & 3 & $74.9 \%$ & $75.3 \%$ & $75.6 \%$ & $78.4 \%$ \\
\hline & $\mathrm{H}_{2} \max$ & $74.0 \%$ & $74.5 \%$ & $74.9 \%$ & $78.2 \%$ \\
\hline \multirow{4}{*}{0.35} & CO $\max$ & $73.8 \%$ & $74.1 \%$ & $74.2 \%$ & $76.4 \%$ \\
\hline & 2 & $73.1 \%$ & $73.4 \%$ & $73.7 \%$ & $76.2 \%$ \\
\hline & 3 & $72.8 \%$ & $73.1 \%$ & $73.4 \%$ & $76.0 \%$ \\
\hline & $\mathrm{H}_{2} \max$ & $72.0 \%$ & $72.3 \%$ & $72.8 \%$ & $76.0 \%$ \\
\hline \multirow{4}{*}{0.4} & CO $\max$ & $71.3 \%$ & $71.5 \%$ & $71.7 \%$ & $73.9 \%$ \\
\hline & 2 & $71.0 \%$ & $71.2 \%$ & $71.4 \%$ & $73.8 \%$ \\
\hline & 3 & $70.7 \%$ & $70.8 \%$ & $71.2 \%$ & $73.7 \%$ \\
\hline & $\mathrm{H}_{2} \max$ & $70.0 \%$ & $70.2 \%$ & $70.7 \%$ & $73.7 \%$ \\
\hline
\end{tabular}

Figure 6 shows that, for indirect gasification, the compression work for the product gas dominates the specific electricity consumption per energy unit of product gas at higher pressures, again being higher for higher $\mathrm{H}_{2} / \mathrm{CO}$ ratios due to the larger volume flow. The flue gas blower consumption for indirect gasification is constant and 
not significant since both the gasification and combustion process operate at atmospheric pressure with the product gas being compressed to delivery pressure downstream of the gasification process. The discontinuities in the curves of Figure 6 are at points where changes in number of compression stages occur due to compression ratio limits (see Table 3). Due to pressure drop in the upstream gasification and product gas cleaning operations the pressure prior to compression for the indirect gasification technology is below atmospheric and the discontinuities do not occur at 4 and 16 bar, respectively, but already at lower gas delivery pressures. For direct gasification, the ASU is the major contributor to the electricity consumption and the influence of pressure is less pronounced. At atmospheric pressure, the specific electricity consumption for direct gasification exceeds the one for indirect gasification by a factor of three. $w_{\text {gasif }}$ for indirect gasification exceeds the values for direct gasification in the pressure range from 3 to 8 bar, depending on the $\mathrm{H}_{2} / \mathrm{CO}$ ratio. The potential for electricity generation given by the specific steam exergy output $w_{\text {steam }}$ is constant over the whole range of product gas delivery pressure for indirect gasification. For direct gasification there exists a slight dependence on the pressure, mainly due to effects of changing numbers of compressor stages as well as varying compressor outlet temperatures. This leads to varying heat loads in heat exchangers (refer to Fig. 4b) and in consequence to small variations in $w_{\text {steam }}$. However, the values determined for $w_{\text {steam }}$ clearly indicate that is possible to cover the electricity demand internally when integrating a steam power cycle, even when accounting for exergy losses in the turbomachinery part (well below $20 \%$ based on [40]).
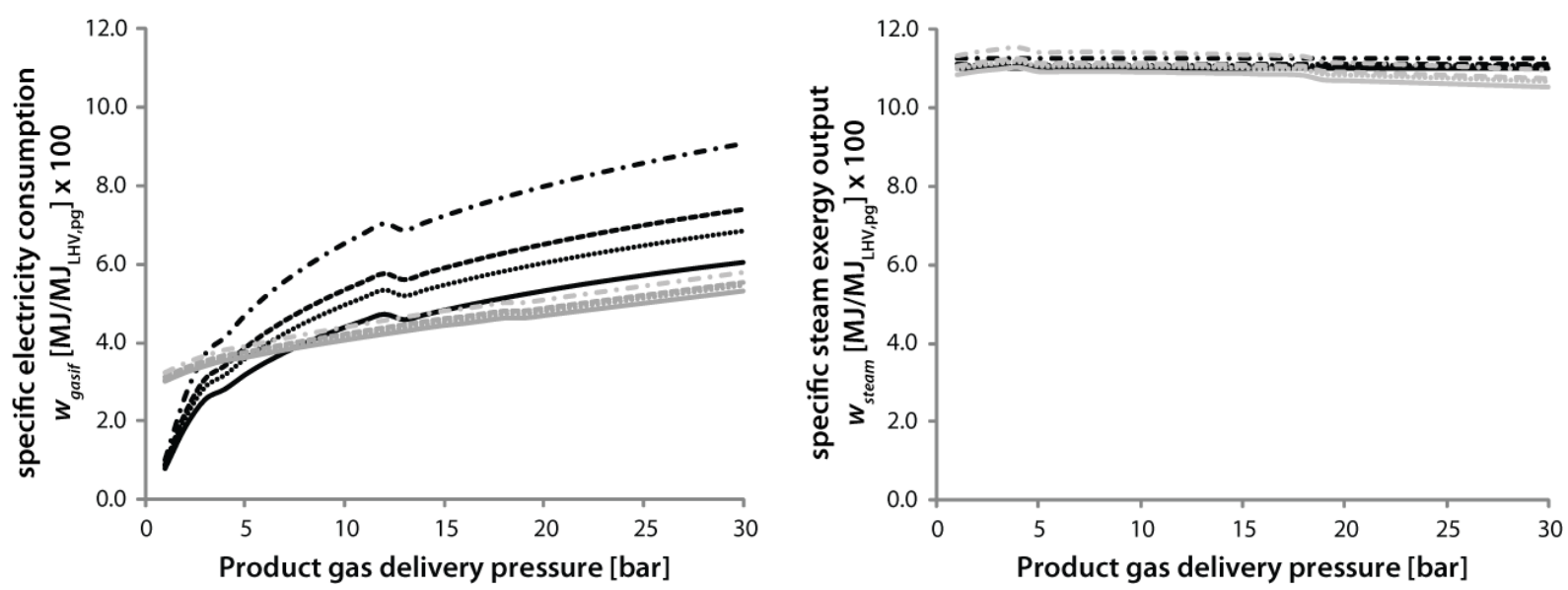

Figure 6: Specific electricity consumption $w_{\text {gasif }}$ (left) and steam exergy output $w_{\text {steam }}$ (right) for the two gasification technologies at $\lambda=\mathbf{0 . 3 5}$ (black: indirect gasification, grey: direct gasification; Solid line $-C O$ max, dotted line $\mathrm{H}_{2} / \mathrm{CO}=2$, dashed line $\mathrm{H}_{2} / \mathrm{CO}=3$, dash-dotted line $-\mathrm{H}_{2}$ max). The discontinuities in the curves are at points where changes in number of compression stages occur due to compression ratio limits (see Table 3).

When considering the downstream process operations within the Bio-SNG process, the concentration of $\mathrm{CO}_{2}$ in the product gas is of particular interest as it needs to be separated using energy-intensive processes. In Figure 7 the molar fraction of $\mathrm{CO}_{2}$ is illustrated for $\lambda=0.35$. Even at atmospheric pressure the $\mathrm{CO}_{2}$ concentration in the product gas for direct gasification is substantially higher due to the fact that the combustion products supplying the gasification energy are present in the product gas. The difference increases with pressure due to the increased amount of inert gas necessary for the pressurised direct gasification. For the $C O$ max case, the relative increase in $\mathrm{CO}_{2}$ concentration is about $50 \%$ from 1 to 30 bar whereas it is about $15 \%$ for the $H_{2}$ max case. The specific amount of feed gas used for direct gasification increases linearly from $0.013 \mathrm{Nm}^{3} \mathrm{CO}_{2} / \mathrm{kg}$ biomass $(0.566 \mathrm{~mol}$ $\mathrm{CO}_{2} / \mathrm{s}$ for $1 \mathrm{~kg} / \mathrm{s}$ of biomass) at 1 bar product gas delivery pressure to $0.296 \mathrm{Nm}^{3} \mathrm{CO}_{2} / \mathrm{kg}$ biomass at 30 bar. For indirect gasification operating at atmospheric conditions with compression of the product gas to delivery pressure, the specific amount of feed gas is constant over the whole pressure range at $0.011 \mathrm{Nm}^{3} \mathrm{CO}_{2} / \mathrm{kg}$ biomass. This number is even lower than for direct gasification delivering product gas at 1 bar due to the fact that direct gasification is operated at slightly higher pressure to compensate for all downstream pressure drops (refer to Fig.4). Improvements in the feeding system reducing the gas void fraction could decrease these numbers but the $\mathrm{CO}_{2}$ concentration in the product gas for direct pressurised gasification will increase with increasing reactor pressure. 
The final publication is available at http://link.springer.com/article/10.1007/s13399-013-0079-1. Published in Biomass Conversion and Biorefinery 2013, DOI: 10.1007/s13399-013-0079-1

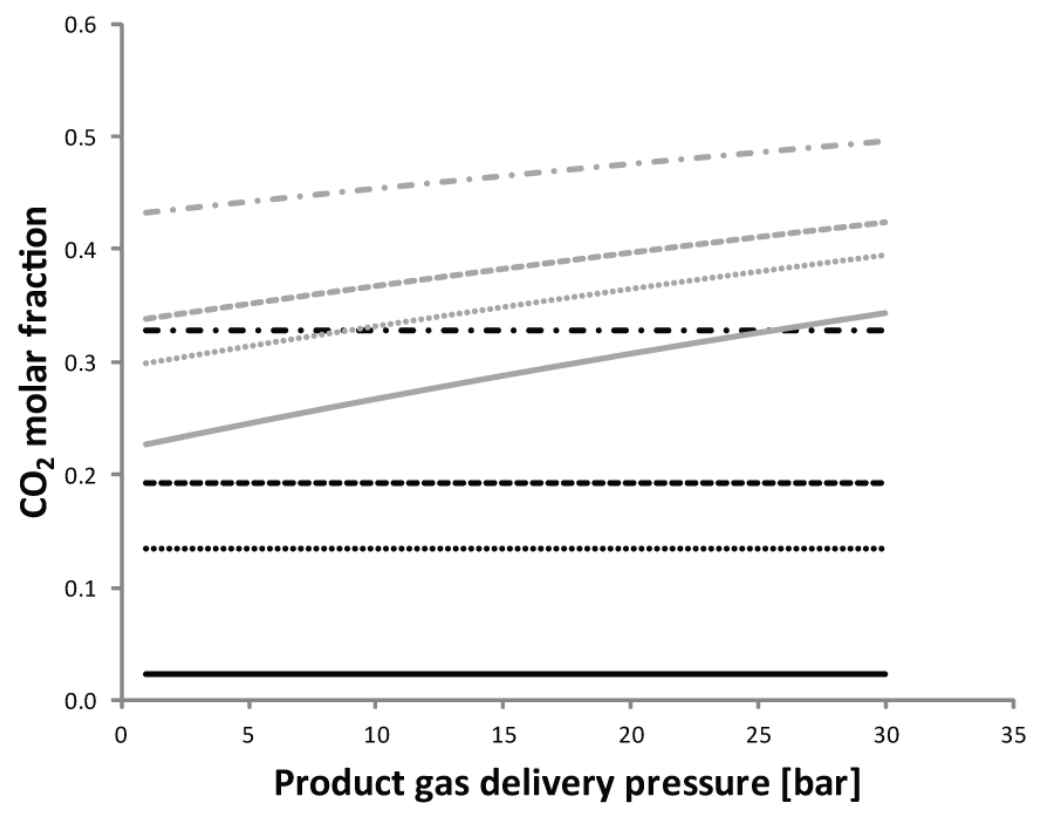

Figure 7: $\mathrm{CO}_{2}$ fraction in product gas for the indirect (black) and direct (grey) gasification concepts at $\lambda=$ 0.35 for varying $\mathrm{H}_{2} / \mathrm{CO}$ ratios. Solid line - $\mathrm{CO}$ max, dotted line $\mathrm{H}_{2} / \mathrm{CO}=2$, dashed line $\mathrm{H}_{2} / \mathrm{CO}=3$, dashdotted line $\mathrm{H}_{2}$ max.

This in consequence implies a penalty on the exergy efficiency when accounting for downstream $\mathrm{CO}_{2}$ separation. Figure 8 illustrates the effect of accounting for the $\mathrm{CO}_{2}$ penalty on the exergy efficiency according to eq. (7) for two selected cases. It can be seen that the direct gasification performance is decreased below indirect gasification efficiency. The increase in $\mathrm{CO}_{2}$ with direct gasification pressure causes the exergy efficiency to decline with further increase in pressure after a maximum at around 10 bar for the presented cases. Reduced entrainment with the feeding system will minimized the dampening effect on the exergy efficiency with increasing pressure, but direct gasification efficiency will still be below indirect gasification gasification efficiency at atmospheric pressure.
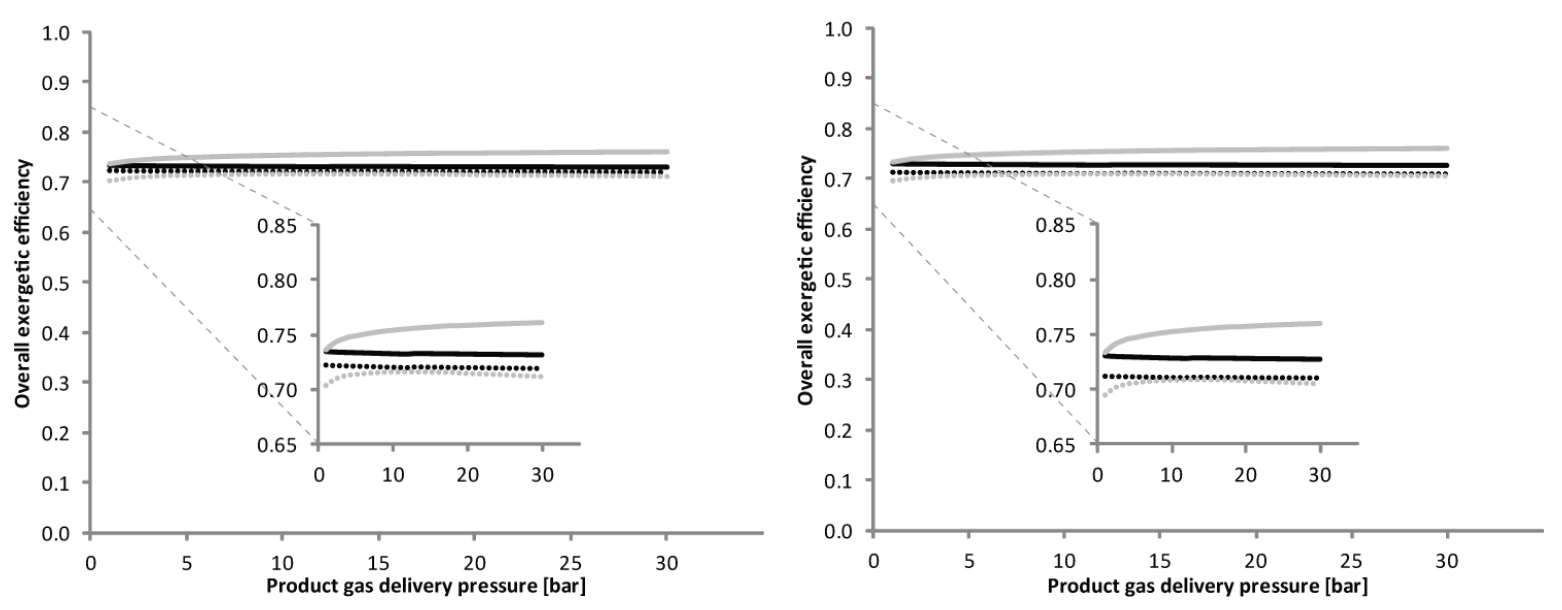

Figure 8: Exergy efficiency of the two systems including losses $\eta_{\text {ex,loss }}$ at $\lambda=0.35$ for two $\mathrm{H}_{2} / \mathrm{CO}$ ratios (left $\mathrm{H}_{2} / \mathrm{CO}=2$, right $\mathrm{H}_{2} / \mathrm{CO}=3$ ). Black lines - indirect gasification, grey lines - direct gasification. Dotted lines represent modified exergy efficiency $\eta_{e x, l o s s \mathrm{CO} 2}$ accounting for $\mathrm{CO}_{2}$ separation exergy penalty.

In order to illustrate the sources of exergy performance decrease for the two technologies in more detail, the different in- and outputs as well as the exergy losses are depicted in Table 7 for a selected case at 10 bar based on an exergetic input of biomass of $100 \mathrm{MW}$. For indirect gasification the major sources of electricity consumption are the product gas compressor and the flue gas blower whereas it is the air separation unit and the 
The final publication is available at http://link.springer.com/article/10.1007/s13399-013-0079-1. Published in Biomass Conversion and Biorefinery 2013, DOI: 10.1007/s13399-013-0079-1

oxygen compressor for the direct gasification. Direct gasification produces larger amounts of product gas on an exergetic basis and the steam generation is similar for both technologies. The major source of exergy loss is the gasification process itself accounting for about $74 \%$ of the losses. It is higher for the indirect gasification due to the fact that the internal heat transfer between combustion and gasification chamber inevitably causes exergy losses. Another important source of loss is heat transfer from the product gas to the steam cycle. For the direct gasification the air separation unit represents an important source of exergy loss while for the indirect gasification the flue gas (leaving the system at just below $100^{\circ} \mathrm{C}$ ) and compressors losses are of importance. Finally, the heat loss from the gasification unit is also a significant source of exergy loss. The remainder of the exergy loss sources is in the range of or below $1 \%$ of the total exergy losses within the system. As already mentioned the gasification steam preheating with steam extraction can cause higher losses to some extent when more steam is added to the gasifier to achieve a higher $\mathrm{H}_{2} / \mathrm{CO}$ ratio.

Table 7: Exergy flows for the two gasification concepts at $10 \mathrm{bar}, \lambda=0.35$ and $\mathrm{H}_{2} / \mathrm{CO}=2$.

Indirect gasification

\begin{tabular}{|c|c|c|c|c|c|}
\hline & \\
\hline & MW & $\%$ & & MW & $\%$ \\
\hline Input & 104.22 & 100.0 & Input & 104.01 & 100.0 \\
\hline Biomass & 100 & 95.9 & Biomass & 100 & 96.1 \\
\hline Electricity & 3.33 & 3.2 & Electricity & 2.78 & 2.7 \\
\hline Product gas compressor & 2.98 & $89.5^{a}$ & $A S U$ & 2.00 & $71.7^{a}$ \\
\hline Flue gas blower & 0.32 & $9.5^{a}$ & Oxygen compressor & 0.58 & $20.7^{a}$ \\
\hline Steam extraction & 0.77 & 0.7 & Steam extraction & 0.74 & 0.7 \\
\hline Other material streams & 0.12 & 0.1 & Other material streams & 0.49 & 0.5 \\
\hline Output & 76.33 & 100.0 & Output & 78.49 & 100.0 \\
\hline Product gas & 68.05 & 89.2 & Product gas & 70.33 & 89.6 \\
\hline HP steam generation & 8.20 & 10.7 & HP steam generation & 8.16 & 10.4 \\
\hline District heat & 0.08 & 0.1 & & & \\
\hline Exergy losses & 27.89 & 100.0 & Exergy losses & 25.52 & 100.0 \\
\hline Gasification process & 20.59 & 73.8 & Gasification process & 19.05 & 74.6 \\
\hline $\begin{array}{l}\text { Heat transfer losses steam } \\
\text { cycle }\end{array}$ & 2.78 & 9.9 & $\begin{array}{l}\text { Heat transfer losses steam } \\
\text { cycle }\end{array}$ & 3.07 & 12.0 \\
\hline Gasification heat loss & 1.32 & 4.7 & ASU & 1.73 & 6.8 \\
\hline Flue gas loss & 1.28 & 4.6 & Gasification heat loss & 1.30 & 5.1 \\
\hline Compressors & 0.79 & 2.8 & Compressors & 0.18 & 0.7 \\
\hline Steam preheat & 0.37 & 1.3 & Steam preheat & 0.16 & 0.6 \\
\hline Scrubber exergy loss & 0.19 & 0.7 & Oxygen preheat & 0.02 & 0.1 \\
\hline Heat transfer losses DH & 0.15 & 0.5 & Pressure drop related & 0.02 & 0.1 \\
\hline Air preheat & 0.15 & 0.5 & & & \\
\hline Pressure drop related & 0.26 & 0.9 & & & \\
\hline Product gas reheat & 0.02 & 0.1 & & & \\
\hline$\eta_{\text {ex,loss }}$ & 0.732 & & $\eta_{e x, l o s s}$ & 0.754 & \\
\hline $\begin{array}{l}\eta_{\text {ex,loss } \mathrm{CO} 2} \\
\text { fraction of electricity input }\end{array}$ & 0.720 & & $\eta_{\text {ex,lossCO2 }}$ & 0.716 & \\
\hline
\end{tabular}

\section{Direct gasification}

78.49

0.0 


\section{Discussion}

The results of the ideal process comparison indicate that pressurised operation of the gasification reactor achieves higher exergetic performance within the whole parameter range investigated. Pressurised indirect gasification even outperforms pressurised direct gasification options by $1 \%$-point. However, this configuration would be a rather complex one with two pressurised vessels and an air compressor for the combustion unit and turbine for recovering the pressure energy of the flue gases. Practical issues such as particulate matter in the flue gases as well as a more complex pressure balance to be handled between the gasification and combustion vessel make this option unlikely to be realized.

For the process comparison including losses the exergy efficiency of the indirect gasification process is more or less constant over the whole pressure range while pressurised direct gasification performance improves with higher pressure and outperforms indirect gasification by 2-3\%-points. However, the $\mathrm{CO}_{2}$ concentration in the product gas for direct gasification is substantially higher compared to indirect gasification putting a penalty on the performance if the $\mathrm{CO}_{2}$ must be separated as is the case in e.g. a Bio-SNG production process in particular and gasification-based biofuel synthesis processes in general. Increasing the reactor pressure for direct gasification even increases the penalty due to a larger amount of $\mathrm{CO}_{2}$ entrained with the feeding system. Little data is available on feeding systems' inertisation gas demands and the numbers assumed imply a certain level of uncertainty. Design of pressurised gasification units will aim at minimizing the entrainment of $\mathrm{CO}_{2}$ as inertisation material. The exergy penalty for $\mathrm{CO}_{2}$ separation might in consequence increase less with increasing product gas delivery pressure for direct gasification, but $\eta_{\text {ex,losses, }, \mathrm{CO} 2}$ at atmospheric conditions will still be lower for direct gasification than for indirect gasification. Given the current assumptions, the exergy penalty on direct gasification decreases the efficiency below indirect gasification exergetic performance for a limiting case of complete separation of the $\mathrm{CO}_{2}$. This trend is of importance even for other biofuel processes based on gasification (such as for example Fischer-Tropsch fuels, methanol, or dimethyl ether) that all include a $\mathrm{CO}_{2}$ separation stage prior to synthesis [41], reducing the potential advantages of pressurised direct gasification due to a higher $\mathrm{CO}_{2}$ removal penalty. The conclusions might differ for a Bio-SNG process when considering $\mathrm{CO}_{2}$ conversion in the methanation section according to eq. (2) by addition of hydrogen from external sources, as proposed for example by Gassner [42].

The large $\mathrm{CO}_{2}$ penalty for direct gasification basically indicates that there is no significant difference in performance for the two gasification technologies within the framework of Bio-SNG production. Consequently, the choice between the two gasification technologies is based on other technical and practical issues. Direct pressurised gasification leads to smaller equipment but at higher complexity whereas indirect gasification implies larger equipment but reduced complexity. In addition, indirect gasification can be operated more flexibly and even allows for integration with existing power generation infrastructure, as proposed by Heyne et al. [43]. Another key issue for Bio-SNG production is the capability of the gasification unit to produce a gas with high $\mathrm{CH}_{4}$ concentration that in turn is related to reactor design and bed material, among other factors. Methane formation has not been accounted for in the current model in order to be able to compare the two technologies on a common basis. Methane formation data from experimental results differ considerably from equilibrium-based estimations. Gasification process design for Bio-SNG production is basically an optimisation process between two conflicting objectives; obtaining high methane yields while keeping tar concentrations at low levels. No superior technology between direct and indirect gasification can be identified per se related to this criterion.

It also has to be kept in mind when analysing the results that a simplified reaction scheme has been applied in order to compare the two technologies on a common basis. The advantage of this approach is that reactor specific differences are not accounted for and the two concepts are compared on a common basis. In reality however, there are a number of aspects that will influence the performance of the processes differently. An important parameter for gasification performance is the carbon conversion efficiency. Considering a decrease in carbon conversion, this will result in direct losses for the direct gasification technology as the unconverted carbon is lost with the bottom and fly ash discharge streams. For indirect gasification a decrease in product gas yield will occur while more carbon will be burnt in the combustion chamber where complete conversion can be ensured. Another dimension to this problem is the disposal of ashes that is not allowed if they contain 
considerable amounts of carbon. A common practice is to burn the ashes with the remaining carbon in an adjacent combustion unit, as is done for example in the Great Plains coal gasification plant [44]. The carbon conversion in a direct gasification process is closely related to the air-to-fuel ratio. The higher the oxygen content in the gasifier the more likely a good carbon conversion can be achieved. The ambition of operating at low air-to-fuel ratios for achieving high fuel conversion efficiency in this case is contradictory to the aim of reaching high carbon conversions. For indirect gasification this is less of a problem as carbon conversion is ensured in the combustion chamber or an additional post-combustion chamber operating with high excess air. Generally, for both gasification technologies improvements compared to the presented results can be achieved by reducing the relative air-to-fuel ratio in order to maximise the product gas yield. The chosen air-to-fuel ratios were selected to enable a comparison on similar basis considering product gas composition between the two gasification technologies. Similar effects are obtained by reducing the heat losses that were assumed in this study to be $2 \%$ of the lower heating value thermal input. The effects of these measures will be beneficial in a similar way for both gasification technologies. Another aspect of the simplified model that has to be accounted for is the fact that the product gas produced does not contain any water vapour. This represents a limiting case with complete conversion of the fuel that will not be possible to reach in a real gasification process. Steam addition in excess of the stoichiometric demand is necessary to improve e.g. char gasification. Steam in the product gas will put a higher penalty on the indirect gasification concept as the latent heat of the water vapour is lost during the cooling prior to compression. For the direct gasification process with hot gas cleaning the influence of the water content in the product gas is of minor importance considering the exergy efficiency. In general, the gasification process exergy efficiency decreases with increasing steam addition due to the fact that high temperature heat at the gasification (or combustion) temperature level is used for heating up the steam supplied.

An additional option for improving the performance of both gasification technologies could be to use the excess electricity that amounts to $0.02-0.1 \mathrm{MW} / \mathrm{MW}_{\mathrm{PG}, \mathrm{LHV}}$ (difference between $w_{\text {steam }}$ and $w_{\text {gasif }}$ based on Fig 6 . neglecting turbomachinery losses) in the gasification unit as high temperature heat supply (plasma gasification is used e.g. for waste gasification [45]). This concept - that even could be extended using excess exergy from the down-stream methanation process - allows for a decrease of the air-to-fuel ratio without decreasing fuel conversion to product gas.

Finally, heat recovery in the analysed cases is a large source of exergy losses besides the gasification step itself but also leads to generation of an important exergy output improving the performance of the process. Current process designs based on biomass gasification do not integrate a steam cycle for heat recovery but often use a hot oil circuit supplying heat to sinks within the process or externally [e.g. [1,46]]. This is mainly due to material issues, impurities in the product gas with tar being the major obstacle, and scale of size making steam cycle integration unfeasible. Future large scale production units should aim at steam cycle integration to improve process performance and process economics. The gas cleaning chain is of particular importance in that respect. A tar free product gas is necessary to safely recover most of the heat. Hot gas cleaning of the product gas considerably increases opportunities for an efficient recovery of the sensible heat from the product gases and the technology is by no means restricted to direct gasification. Chemical-looping reforming is such an example of high temperature tar reforming that is investigated for indirect atmospheric gasification [25,47]. Assuming hot gas cleaning for the indirect gasification process in this study would lead to a slight increase in exergy efficiency. Similarly cold gas cleaning would penalize the direct gasification process. However, the sensible heat losses when applying a scrubber for final particle removal in the cold gas cleaning chain are of minor importance for the overall process efficiency as illustrated by the exergy losses shown in Table 7 . The focus for efficient process design needs to be on overcoming restrictions for high temperature heat recovery that do exist in real processes but have not been accounted for in this study.

\section{Conclusions}

This paper presented the results of an exergy-based comparison of indirect and direct biomass gasification technologies within the framework of production of Bio-SNG. The performance of the gasification and gas cleaning processes are investigated for a simplified gasification reaction scheme with the product gas delivery pressure as the main parameter investigated. Calculated cold gas efficiencies (lower heating value basis) for the 
gasification processes range from 0.665 to 0.842 for a product gas delivery pressure range of 1 to 30 bar within the whole parameter domain investigated. The varied parameters are the relative air-to-fuel ratio $\lambda(0.3$ to 0.4$)$ and the $\mathrm{H}_{2} / \mathrm{CO}$ ratio, that was varied from cases with maximum $\mathrm{CO}$ yield (cases $\mathrm{CO}$ max with lowest $\mathrm{H}_{2} / \mathrm{CO}$ ratio of 1.08 for $\lambda=0.3$ ) to complete conversion of $\mathrm{CO}$ to $\mathrm{H}_{2}$ by the water gas shift reaction (cases $\mathrm{H}_{2}$ max with $\mathrm{H}_{2} / \mathrm{CO}=\infty$ ). The exergy performance results of comparable ideal processes indicate a slight advantage for the pressurised gasification process that achieves exergetic efficiency values that are 2-3\%-points higher compared to atmospheric gasification in the higher pressure range (about 81-83\% for direct pressurised compared to 79$81 \%$ for indirect atmospheric, within the studied range of relative air-to-fuel and $\mathrm{H}_{2} / \mathrm{CO}$ ratio values). Even when a number of important source of losses are considered, pressurised gasification is still shown to achieve superior performance by up to $3 \%$-points in exergy efficiency at 30 bar. However, when considering Bio-SNG production with $\mathrm{CO}_{2}$ separation as an inherent process step, a higher exergy penalty associated for the pressurised direct gasification process makes the two gasification processes perform similarly with an exergy efficiency in the range of 0.7-0.72. It is concluded that neither direct nor indirect gasification can be identified as intrinsically superior for Bio-SNG production based on the results presented. The key aspect for biomass gasification is the efficient heat integration and cogeneration of power rather than the choice of gasification technology. In particular the conversion of high temperature process heat to steam for power generation contributes considerably to the exergy output from the process, standing for about $10 \%$ with the product gas exergy representing the remaining $90 \%$. Considering the gasification step itself, high fuel conversion to product gas is the main objective for both technologies. Lowered carbon conversion is a threat in particular for direct gasification as the unconverted carbon cannot be used efficiently within the process as is the case for indirect gasification.

\section{Acknowledgements:}

This project was funded by the Swedish Energy Agency's program for Energy Efficiency in Industry, Göteborg Energi's Research Foundation, and E.ON as well as the Swedish Gasification Centre (SFC).

\section{Nomenclature}

$\begin{aligned} & \text { Symbols \& Abbreviations } \\ & A S U \text { air separation unit } \\ & e \text { specific exergy } \\ & \text { (mass) } \\ & \dot{E} \text { exergy flow } \\ & H H V \text { higher heating } \\ & \text { value } \\ & \dot{m} V \text { lower heating value } \\ & M \text { mass flow } \\ & P \text { pressure mass } \\ & R \text { gas constant } \\ & T \text { temperature } \\ & w \text { specific work } \\ & \dot{W} \text { work flow/power } \\ & \lambda \text { relative air-to-fuel } \\ & \eta \text { ratio } \\ & \varphi \text { efficiency } \\ & \varphi \text { effective solid } \\ & \rho \text { volume fraction } \\ & \Pi \text { comprity } \\ & \text { Indices } \\ & \text { air } \text { air } \\ & c g \text { biomass } \\ & \text { cold gas }\end{aligned}$

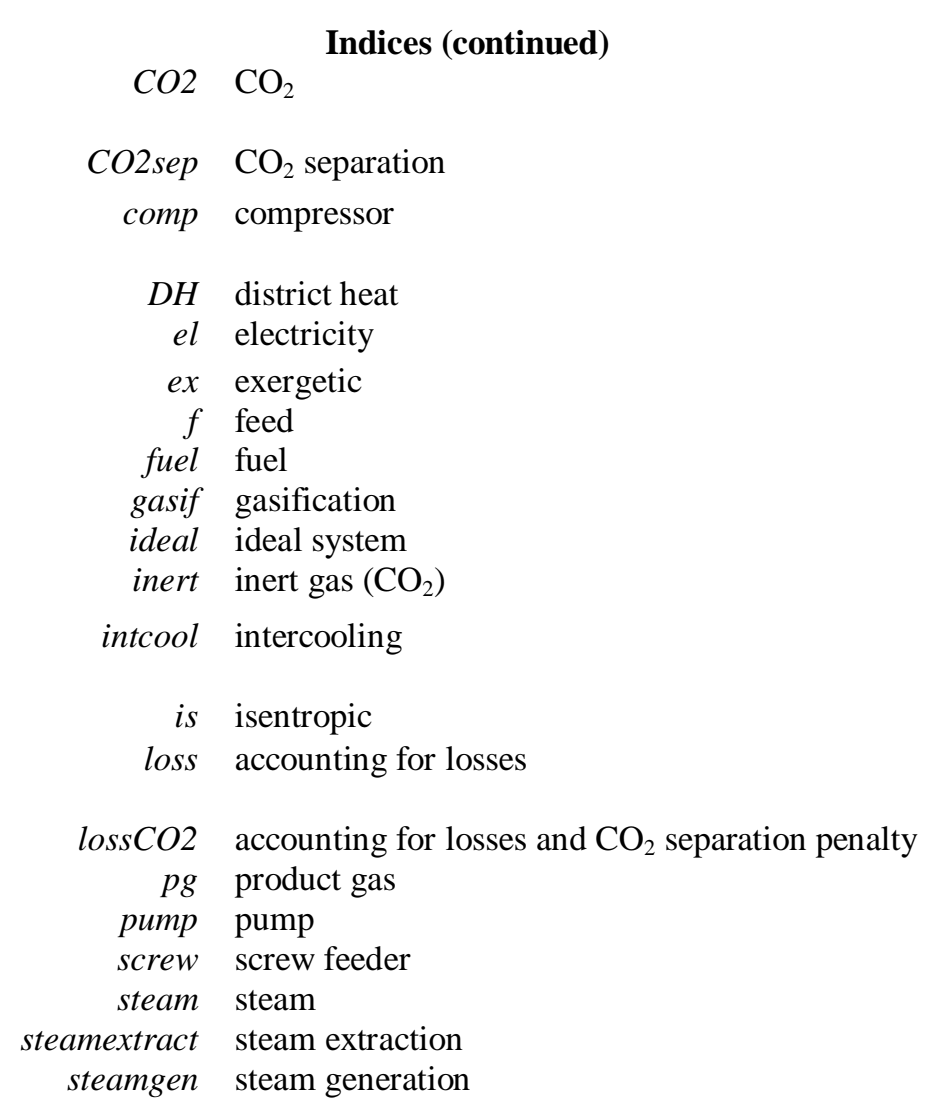


The final publication is available at http://link.springer.com/article/10.1007/s13399-013-0079-1. Published in Biomass Conversion and Biorefinery 2013, DOI: 10.1007/s13399-013-0079-1

\section{References}

1. Gunnarsson I (2011) The GoBiGas Project. International Seminar on Gasification 2011 - Gas Quality, CHP and New Concepts, Malmö, Sweden, October 6-7 2011

2. Fredriksson Möller B (2011) The E.ON Bio2G Project. International Seminar on Gasification 2011 - Gas Quality, CHP and New Concepts, Malmö, Sweden, October 6-7 2011

3. Adelt M, Vogel A (2010) Bio-SNG - Prospective renewable energy carrier in the E.ON gas grid (in German: Bio-SNG zukünftiger regenerativer Energiträger im E.ON Gasnetz). Erdöl Erdgas Kohle 126 (10):338-341

4. Hennius M (2012) E.ON delays large-scale biogas project in Scania (In Swedish: E.ON avvaktar med storskaligt biogasprojekt i Skåne). Press release. E.ON Sverige AB, Malmö

5. Hamelinck CN, Faaij APC (2006) Outlook for advanced biofuels. Energy Policy 34 (17):32683283. doi:10.1016/j.enpol.2005.06.012

6. van der Meijden CM, Veringa HJ, Rabou LPLM (2010) The production of synthetic natural gas (SNG): A comparison of three wood gasification systems for energy balance and overall efficiency. Biomass and Bioenergy 34 (3):302-311. doi:10.1016/j.biombioe.2009.11.001

7. Gassner M, Maréchal F (2012) Thermo-economic optimisation of the polygeneration of synthetic natural gas (SNG), power and heat from lignocellulosic biomass by gasification and methanation.

Energy and Environmental Science 5 (2):5768-5789. doi:10.1039/c1ee02867g

8. Gassner M, Maréchal F (2009) Thermo-economic process model for thermochemical production of Synthetic Natural Gas (SNG) from lignocellulosic biomass. Biomass and Bioenergy 33 (11):15871604. doi:10.1016/j.biombioe.2009.08.004

9. Rönsch S, Kaltschmitt M (2012) Bio-SNG production - concepts and their assessment. Biomass Conversion and Biorefinery 2 (4):285-296. doi:10.1007/s13399-012-0048-0

10. Karellas S, Panopoulos KD, Panousis G, Rigas A, Karl J, Kakaras E (2012) An evaluation of Substitute natural gas production from different coal gasification processes based on modeling. Energy 45 (1):183-194. doi:10.1016/j.energy.2012.03.075

11. Channiwala SA, Parikh PP (2002) A unified correlation for estimating HHV of solid, liquid and gaseous fuels. Fuel 81 (8):1051-1063. doi:10.1016/S0016-2361(01)00131-4

12. Szargut J, Morris DR, Steward FR (1988) Exergy analysis of thermal, chemical, and metallurgical processes. Hemisphere, New York

13. Schuster G, Loffler G, Weigl K, Hofbauer H (2001) Biomass steam gasification - an extensive parametric modeling study. Bioresource Technology 77 (1):71-79. doi:10.1016/S0960-

8524(00)00115-2

14. Kopyscinski J, Schildhauer TJ, Biollaz SMA (2010) Production of synthetic natural gas (SNG)

from coal and dry biomass - A technology review from 1950 to 2009 . Fuel 89 (8):1763-1783.

doi:10.1016/j.fuel.2010.01.027

15. Friedrichs G, Proplesch P, Lommerzheim W (1982) Comflux pilot plant for converting coal conversion gas into SNG. Gaswärme International 31 (6):261-264

16. Seemann M (2006) Methanation of biosyngas in a fluidized bed reactor. PhD thesis, Swiss Federal Institute of Technology, Zürich, Switzerland

17. Hannula I, Kurkela E (2012) A parametric modelling study for pressurised steam $/ \mathrm{O}_{2}$-blown

fluidised-bed gasification of wood with catalytic reforming. Biomass and Bioenergy 38:58-67.

doi:10.1016/j.biombioe.2011.02.045

18. Siedlecki M, de Jong W (2011) Biomass gasification as the first hot step in clean syngas production process - gas quality optimization and primary tar reduction measures in a $100 \mathrm{~kW}$ thermal input steam-oxygen blown CFB gasifier. Biomass and Bioenergy 35 (SUPPL. 1):S40-S62.

doi:10.1016/j.biombioe.2011.05.033

19. Kitzler H, Pfeifer C, Hofbauer H (2011) Pressurized gasification of woody biomass-Variation of parameter. Fuel Processing Technology 92 (5):908-914. doi:10.1016/j.fuproc.2010.12.009

20. Puchner B, Pfeifer C, Hofbauer H (2009) Bed material and parameter variation for a pressurized biomass fluidized bed process. In: Yue G, Zhang H, Zhao C, Luo Z (eds) 20th International 
The final publication is available at http://link.springer.com/article/10.1007/s13399-013-0079-1. Published in Biomass Conversion and Biorefinery 2013, DOI: 10.1007/s13399-013-0079-1

Conference on Fluidized Bed Combustion, Xian, China, May 18-21 2009. Tsinghua University Press, Beijing and Springer-Verlag Berlin Heidelberg, pp 700-705. doi:10.1007/978-3-642-02682-9_108 21. Valin S, Ravel S, Guillaudeau J, Thiery S (2010) Comprehensive study of the influence of total pressure on products yields in fluidized bed gasification of wood sawdust. Fuel Processing Technology 91 (10):1222-1228. doi:10.1016/j.fuproc.2010.04.001

22. Lind F, Israelsson M, Seemann M, Thunman H (2012) Manganese oxide as catalyst for tar cleaning of biomass-derived gas. Biomass Conversion and Biorefinery 2 (2):133-140.

doi:10.1007/s13399-012-0042-6

23. Zwart RWR, Van Der Drift A, Bos A, Visser HJM, Cieplik MK, Könemann HWJ (2009) Oil-

Based gas washing- flexible tar removal for high-efficient production of clean heat and power as well as sustainable fuels and Chemicals. Environmental Progress and Sustainable Energy 28 (3):324-335. doi:10.1002/ep.10383

24. Pröll T, Aichernig C, Rauch R, Hofbauer H (2007) Fluidized bed steam gasification of solid biomass - Performance characteristics of an $8 \mathrm{MWth}$ combined heat and power plant. International Journal of Chemical Reactor Engineering 5:54. doi:10.2202/1542-6580.1398

25. Lind F, Seemann M, Thunman H (2011) Continuous catalytic tar reforming of biomass derived raw gas with simultaneous catalyst regeneration. Industrial and Engineering Chemistry Research 50 (20):11553-11562. doi:10.1021/ie200645s

26. Pfeifer C, Hofbauer H (2008) Development of catalytic tar decomposition downstream from a dual fluidized bed biomass steam gasifier. Powder Technology 180 (1-2):9-16.

doi:10.1016/j.powtec.2007.03.008

27. Brodén H, Nyström O, Jönsson M (2012) Optimum power yield for bio fuel fired combined heat and power plants (In Swedish: Optimal elverkningsgrad för biobränsleeldade kraftvärmeverk). Värmeforsk, Stockholm

28. Dai J, Cui H, Grace JR (2012) Biomass feeding for thermochemical reactors. Progress in Energy and Combustion Science 38 (5):716-736. doi:10.1016/j.pecs.2012.04.002

29. Cummer KR, Brown RC (2002) Ancillary equipment for biomass gasification. Biomass and Bioenergy 23 (2):113-128. doi:10.1016/S0961-9534(02)00038-7

30. Swanson ML, Musich MA, Schmidt DD, Schultz JK (2003) Feed system innovation for gasification locally economical alternative fuels (FIGLEAF). U.S. Department of Energy, National Energy Technology Laboratory, Pittsburgh, PA

31. Jones D, Bhattacharyya D, Turton R, Zitney SE (2011) Optimal design and integration of an air separation unit (ASU) for an integrated gasification combined cycle (IGCC) power plant with $\mathrm{CO}_{2}$ capture. Fuel Processing Technology 92 (9):1685-1695. doi:10.1016/j.fuproc.2011.04.018

32. Beysel G (2009) Enhanced Cryogenic Air Separation - A proven process applied to Oxyfuel:

Future Prospects. 1st International Oxyfuel Combustion Conference, Cottbus, Germany, September 8112009

33. Tranier J-P, Dubettier R, Perrin N (2009) Air Separation Unit for Oxy-Coal Combustion Systems. Paper presented at the 1st International Oxyfuel Combustion Conference, Cottbus, Germany, 34. Aspen Engineering Suite V7.2 (2010). Aspen Technology Inc.

35. Edberg U, Engstrom L, Hartler N (1973) The influence of chip dimensions on chip bulk density. Svensk Papperstidning 14:529-533

36. Plötze M, Niemz P (2011) Porosity and pore size distribution of different wood types as determined by mercury intrusion porosimetry. European Journal of Wood and Wood Products 69 (4):649-657. doi:10.1007/s00107-010-0504-0

37. Screw conveyor speed calculation. (2013) Bulk Handling Global Pty Ltd.

http://www.bulksolidsflow.com/free_programs/screw_conveyor_design/screw_conveyor_design.html. Accessed February 282013

38. Rautalin A, Wilén C (1992) Feeding biomass into pressure and related safety engineering. VTT

Research Notes 1428. VTT - Technical Research Centre of Finland, Espoo

39. Götz M, Köppel W, Reimert R, Graf F (2012) Potential to Optimize Scrubbers for Biogas

Cleaning Part 2. Chemical Scrubbers (in German; Optimierungspotenzial von Wäschen zur

Biogasaufbereitung Teil 2. Chemische Wäschen). Chemie Ingenieur Technik 84 (1-2):81-87.

doi:10.1002/cite.201100129 
The final publication is available at http://link.springer.com/article/10.1007/s13399-013-0079-1. Published in Biomass Conversion and Biorefinery 2013, DOI: 10.1007/s13399-013-0079-1

40. Stecco SS, Manfrida G (1986) Exergy analysis of compression and expansion processes. Energy 11 (6):573-577. doi:http://dx.doi.org/10.1016/0360-5442(86)90105-2

41. Tock L, Gassner M, Maréchal F (2010) Thermochemical production of liquid fuels from biomass: Thermo-economic modeling, process design and process integration analysis. Biomass and Bioenergy 34 (12):1838-1854

42. Gassner M, Maréchal F (2008) Thermo-economic optimisation of the integration of electrolysis in synthetic natural gas production from wood. Energy 33 (2):189-198. doi:10.1016/j.energy.2007.09.010 43. Heyne S, Thunman H, Harvey S (2012) Extending existing combined heat and power plants for synthetic natural gas production. International Journal of Energy Research 36 (5):670-681. doi:10.1002/er.1828

44. Panek JM, Grasser J (2006) Practical Experience Gained During the First Twenty Years of Operation of the Great Plains Gasification Plant and Implications for Future Projects. US Department of Energy - Office of Fossil Energy, Washington, DC

45. Heberlein J, Murphy AB (2008) Thermal plasma waste treatment. J Phys D-Appl Phys 41 (5). doi:10.1088/0022-3727/41/5/053001

46. Hofbauer H, Rauch R, Loeffler G, Kaiser S, Fercher E, Tremmel H (2002) Six Years Experience with the FICFB-Gasification Process. 12th European Conference and Technology Exhibition on Biomass for Energy, Industry and Climate Protection, Amsterdam, Netherlands, June 17-21 2002 47. Dutta A, Talmadge M, Hensley J, Worley M, Dudgeon D, Barton D, Gronendijk P, Ferrari D, Stears B, Searcy EM, Wright CT, Hess JR (2011) Process Design and Economics for Conversion of Lignocellulosic Biomass to Ethanol. National Renewable Energy Laboratory, Golden, Colorado 